\title{
Packaged Preferences and the Institutional Transformation of Interests
}

\author{
Jonathan R. Macey $\dagger$
}

The point of this Article is to show that mediating institutions are better decision makers than individuals. For this reason, individuals often find it in their interest to select a variety of mediating institutions (corporations, investment funds, unions, pohitical parties, rehgious institutions, etc.) to act as their agents. These mediating institutions will choose packages of preferences on behalf of their principals.

Moreover, I will argue that individual preferences evolve over time. As individuals' investments in their mediating institutions grow over time, these individuals come to identify more closely with these institutions. As a consequence of this phenomenon of "escalating commitments," mediating institutions play a transformative role in people's lives, shaping their preferences in important ways. Thus, I will argue that criticisms of mediating institutions as "unrepresentative" of their constituents are misguided. Members want their institutions to take the lead in identifying alternatives. Because individual decision makers often act irrationally, they do not want their representatives to choose as they would have chosen themselves. Rather, individuals trust their mediating institutions to act as professional decision makers to relieve themselves of the responsibility of making certain decisions.

The tobacco conglomerate Phillip Morris presents a vivid example of the self-conscious power of the mediating institution to shape the preferences of its membership. In a recent interview, Craig L. Fuller, Senior Vice President for Corporate Affairs for Phillip Morris Companies, described his job as similar to his previous job as a chief of staff for George Bush, saying that he tells people "[t]his is who you are and this is what you believe."

$\dagger$ J. DuPratt White Professor of Law, Cornell University. I am grateful for research assistance from Matthew G. Bibbens, Cornell Law School class of 1996, and for research support from Cornell Law School and from the International Centre for Economic Research in Turin, Italy, where much of the research on this Article was conducted. I am also grateful for useful comments and suggestions from Enrico Colombatto, Geoffrey P. Miller, and Jeffrey G. Rachlinski.

1 Roger Rosenblatt, How Do Tobacco Executives Live With Themselves?, NY Times 
Mr. Fuller and his colleagues must be effective; according to the company's president, over the past twenty-seven years, nobody has ever left the corporation as a result of personal, philosophical, or moral concerns about the damage that cigarette smoking is doing to people's health. ${ }^{2}$ Philip Morris is not alone; "people who work for a large, immensely successful company . . . tend to adopt the values of the company, regardless of its product. Loyalty supersedes objectivity."

Thus, mediating institutions-whether corporate, professional, educational, or personal-change the relationship between their members and their government or larger society. While the representative, rent-seeking role of mediating institutions is well recognized, their role in changing individual preferences is not.

This Article stresses the transformative role of mediating institutions in the lives of their members. Mediating institutions actually define the preferences of their constituents, both by making decisions for them and by changing their priorities over time. Studies of this transformative role are best developed in the case of the modern corporation, but the transformation of preferences occurs in other social institutions as well. In addition to forming members' preferences, mediating institutions permit members to focus more exclusively on certain aspects of their lives, by delegating decision-making authority in other areas to such institutions. As the world has become increasingly complex, people simply are unable to process the enormous amount of information necessary for them to make intelligent, or even wellinformed, decisions in all facets of their lives. Mediating institutions permit people to disengage themselves from certain types of decision making because such institutions assume the role of decision maker with respect to issues that fall within the domain of the mediating institution. For example, the Catholic Church has assumed the role of decision maker for members of that religion with respect to the issue of the morality of abortion. People professing to be Catholics can certainly "opt out" of this

Mag 34, 41 (Mar 20, 1994).

2 Id at 73. It seems unlikely that Phillip Morris's remarkable ability to keep its employees from having moral or philosophical concerns about the effects of its tobacco products on people's health is due to self-selection among the company's employees. Phillip Morris recruits among American business schools in the same way as other companies. The executives who work for Philhp Morris enter the company with generic interests in marketing, sales, product development, finance, and other fields. The fact that they are marketing tobacco instead of some other product appears to be almost irrelevant.

3 Id. 
decision-making framework by refusing to subscribe to the position of the Church with respect to this issue. However, for millions of Catholics, membership in the mediating institution called the Catholic Cliurcl provides guidance on the issue of abortion. For these people, the Churcli serves a transformative role, eitlier by choosing the preferences of people witl no fixed views on the issue, or by changing the views of people who might have been pro-choice but for their membership in the Church.

In other words, people believe that if they approve of positions $\mathrm{A}, \mathrm{B}$, and $\mathrm{C}$ adopted by a mediating institution, they will often adopt positions $\mathrm{D}$ througl $\mathrm{Z}$ of that institution, on the assumption that these are the conclusions they themselves would reacl witl respect to those issues if they devoted sufficient time, thought, and study to reacl an informed conclusion. Thus, for example, the rank and file of American labor unions probably know little about the North American Free Trade Agreement (NAFTA). However, labor union members readily accepted the conclusion that ratification of NAFTA was bad policy, at least from their perspective. Religion presents a special case of this phenomenon. Those who accept the transcendent values offered by a particular religion also will accept the positions that accompany those values. The point here is simply that membership in a particular mediating institution causes people to adopt particular preferences and points of view. These are not necessarily the preferences or points of view such people would adopt if they were not members of the mediating institution.

Using the corporate form as a starting point, Section I of this Article discusses how the corporation, as a mediating institution, influences tlie formation of preferences among its various participants. Section I shows that investors' preferences for management schemes are determined not by their individual, innate characteristics, as economists generally presume, but rather by the nature of their relationslip with their firms. Section II discusses the opportunities for disengagement presented by mediating institutions of all kinds. Indeed, I will argue that people at times voluntarily associate themselves with mediating institutions because they want to obtain some of the benefits offered by the institution while disengaging from the activities of that institution. Section II also discusses the normative implications of disengagement. In particular, it seems that, while disengagement may be optimal from the perspective of individual participants within a firm, society as a whole may be worse off as disengagement becomes more widespread. In Section III, I dis- 
cuss the coercive effects of preference-forming institutions on their disengaged members as well as third parties. I suggest that the coercion of members is less troublesome than the coerced formation of rival institutions.

\section{PREFERENCE Formation IN MEDiating INSTITUTIONS}

\section{A. Framed Preferences and Economic Rationality}

The premise held by most liberal thinkers is that people use mediating institutions to achieve certain policy goals, that is, to try to cause their preferences to be transformed into policy. ${ }^{4}$ Indeed, much of traditional economic thinking is based on the assumption that people are "rational economic actors"; that is, they have fixed preferences that can be translated into predictable patterns. By behaving "rationally," consumers are thought to maximize utility and producers to maximize profits. Crudely put, this means that while "consumers are not expected to be wizards," they are deemed to be "fairly consistent in their tastes and actions; [ ] they do not flail around in unpredictable ways, making themselves miserable by persistent errors of judgment or arithmetic."

More formally, economic theory supposes that valuable opportunities do not go unexploited, and that it is therefore unnecessary to protect people from the consequences of their own actions and choices. ${ }^{6}$ But, as Amartya Sen has observed, "[r]ationality may be seen as demanding something other than just consistency .... [Rationality] demand[s] cogent relations between aims and objectives actually entertained by the person and the choices that the person makes." There must be some relationship between a person's choices and her goals or objectives.

However, recent studies make it clear that the economists' basic presumptions about preferences are open to challenge. For example, economists assume that a "rational" decision maker

4 See Steven G. Calabresi, Political Parties as Mediating Institutions, 61 U Chi L Rev 1479, 1526-27 (1994) (discussing how political parties can reduce agency costs by linking political actors to certain preexisting programs and ideas).

5 Paul A. Samuelson and William D. Nordbaus, Economics 451 (McGraw-Hill, 13th ed 1989).

6 See Daniel Kahneman, New Challenges to the Rationality Assumption (Aug 5, 1993) (nanuscript on file with author).

7 Amartya Sen, Rational Behavior, in John Eatwell, et al, eds, 4 The New Palgrave: A Dictionary of Economics 68, 73 (Macmillan, 1987). 
confronted with two different formulations of the same problem would make the same choice with respect to each version, but social science research refutes such assumptions.

Amos Tversky and Daniel Kahneman conducted an experiment showing that the way that a choice is framed or described often will have a determinative effect on people's preferences. ${ }^{8}$ People were told to assume themselves richer by $\$ 300$ and asked to choose between: (a) a sure gain of $\$ 100$, and (b) a 50 percent chance to gain $\$ 200$ and a 50 percent chance to gain nothing. In the experiment, 72 percent of the respondents chose the sure gain of $\$ 100$.

The same people were then told to assume themselves richer by $\$ 500$ and asked to choose between: (c) a sure loss of $\$ 100$, and (d) a 50 percent chance to lose nothing and a 50 percent chance to lose $\$ 200$. One would expect that the outcome of the second choice set would be the same as the outcome of the first. After all, in both choice sets, the decision maker has a choice between $\$ 400$ and a $50-50$ chance of $\$ 500$ or $\$ 300$. But in fact, the outcome was almost symmetrically opposite. In the second experiment, only 36 percent of the decision makers took the sure loss of $\$ 100$, while 64 percent selected the 50-50 chance of losing nothing or losing $\$ 200$.

What seems clear is that initial reference points are of critical importance. People appear to be extremely averse to loss. People even appear to be willing to take risks to avoid what they perceive as losses, while they are not prepared to take even small risks to obtain what they might characterize as gains. Thus, in the first choice-set, most people acted risk averse by overwhelmingly (72 percent) selecting the sure gain of $\$ 100$. In the second choice-set, most people (64 percent) preferred the 50 percent chance of losing $\$ 200$.

Another important challenge to economists' rationality assumption is the so-called endowment effect. People appear to value possessions more than a purely Coaseian analysis might predict. For example, my Cornell colleague Dick Thaler conducted an experiment in which some test takers were given a choice between a decorated mug from the university bookstore (worth about \$6) and a sum of money. ${ }^{9}$ Other test takers were given the

8 Amos Tversky and Daniel Kahneman, Rational Choice and the Framing of Decisions, 59 J Bus S251, S257-62 (1986).

9 Daniel Kahneman, et al, The Endowment Effect, Loss Aversion, and Status Quo Bias, 5 J Econ Perspectives 193, 196-97 (1991). 
decorated mug and then asked a series of questions to determine the amount of money for which they would agree to exchange it. From a rational perspective, the two groups of test takers were in exactly the same position. However, consistent with the presence of an "endowment effect," the people who were given property rights in a mug valued the mug more highly than the test takers who were simply given an abstract choice. ${ }^{10}$

Finally, initial positions and endowment effects often play critical roles in influencing people's ideas about justice and fairness. For example, when asked whether it is fair for a company that is making a small profit but is located in a town that is being buffeted by substantial unemployment to cut wages and salaries by 7 percent when inflation is zero, 63 percent of people responded that such a wage cut would be unfair, and only 37 percent said it would be acceptable. Yet 78 percent said that it would be fair for a company making a small profit but located in a town that is experiencing substantial unemployment and 12 percent inflation to increase salaries by only 5 percent. Both situations involve a 7 percent cut in real wages. Such a cut is considered fair when framed as a nominal wage increase, and unfair when framed as a nominal wage cut. ${ }^{11}$

In sum, while economists assume that people act to try to benefit themselves, a growing body of evidence indicates that people are not particularly skilled at doing so. Indeed, it is impossible to avoid the conclusion that people are not rational and consistent. Lawyers, economists, and others who study the role that institutions play in society must take this shortcoming into account.

One of the principal assertions of this Article is that helping people overcome this deficiency is a critical role for mediating institutions. Mediating institutions do this for people in two ways. First, by economizing on information costs, mediating institutions inform people of what their preferences should be. Mediating institutions serve to order preferences, simplify complexity, and contextualize information for people, not only so that they can make better decisions, but also so that they can become informed by a reliable source about what is best for them. Second,

10 See also Daniel S. Levy and David Friedman, The Revenge of the Redwoods? Reconsidering Property Rights and the Economic Allocation of Natural Resources, $61 \mathrm{U}$ Chi L Rev 493, 506-15 (1994) (discussing this phenomenon with regard to people's "willingness to accept" versus their "willingness to pay" for hard-to-value environmental goods).

11 Kahneman, et al, The Endowment Effect at 204 (cited in note 9). 
and more importantly, mediating institutions can actually shape the preferences of their members. People define themselves as individuals by their membership in particular mediating institutions. By joining a mediating institution, whether it is a country club, a political party, or a particular religious group, people come to identify with the institutional norms and values of those institutions and adopt the preferences of those institutions for their own. In other words, mediating institutions serve as a sort of institutional brokerage or trading floor on which preferences are exchanged. People who come to mediating institutions without fixed preferences over a particular issue simply will find it easier to adopt the institutions' preferences as their own.

Of course, people are not completely without points of view. Some people will have strong views about a particular subject regardless of their affiliation with a particular mediating institution. If these views are sufficiently at odds with membership, then they will quit the institution. But in general, some departure from the perspective of the institution is to be expected. The point is not that people share the views of their mediating institutions with respect to every issue. Rather, the point is simply that mediating institutions shape people's preferences, and not the other way around.

In addition, mediating institutions shape people's preferences by deflining the context in which people make decisions about what their preferences should be. For example, by joining a particular organization, people implicitly accept certain basic presumptions about who they are. These presumptions, in turn, serve to shape people's preferences. In other words, mediating institutions have a deflning culture. People who belong to mediating institutions become immersed in the culture of their institutions. They are likely to adopt preferences that are consistent with the defining culture. For example, members of particular religious groups often hold remarkably similar political beliefs. Jews in the United States are not only more politically left of center than other religious groups, they are also far more liberal than other U.S. ethnic groups (including WASPs) with similar incomes. ${ }^{12}$ There is nothing particular in the Jewish religion that leads to such political beliefs. Rather, the more likely explanation for this phenomenon is that, over time, the dominant culture of the Jewish religion has come to be defined as a liberal theology.

12 See Jonathan R. Macey, The Role of the Democratic and Republican Parties as Organizers of Shadow Interest Groups, 89 Mich L Rev 1, 21-22 (1990). 
Members adopt this liberal ideology even though it is potentially costly (in the form of higher taxes, etc.) because they want to conform to the dominant culture of what may be the most important mediating institution in their lives.

These observations about preference formation should lead to a fundamental change in the way that we view mediating institutions. Traditional Western liberal thinking treats them as conduits for nurturing and support among similarly situated people with shared perspectives. Ronald Dworkin's views reflect this:

Someone to whom religion is of fundamental importance, for example, will obviously lead a very different and perhaps more satisfying life in a community in which most other people share his convictions than in a dominantly secular society of atheists for whom his beliefs are laughable superstitions. A woman who believes that explicit sexual material degrades her will likely lead a very different, and no doubt more satisfying, life among people who also despise pornography than in a community where others, including other women, think it liberating and fun. ${ }^{13}$

While this perspective contains an element of truth, it does not stress the ability of mediating institutions to determine preferences on behalf of people with no firm convictions on a particular matter. As Dworkin points out, people with strong beliefs about religion or pornography will be drawn toward certain mediating institutions. But once those people have joined a particular mediating institution, that institution may play a large role in influencing its members' preferences over a wide range of ancillary and unrelated matters. Thus, a person's affiliation with a particular religious group will influence far more than that person's views about biblical interpretation or abortion; the institution may shape members' preferences about such apparently nondetermined issues as welfare benefits for unwed mothers, environmental policy, animal rights, or even the legality of bingo games. Likewise, the groups that one joins in search of solidarity on the pornography issue are likely to have a strong influence on one's views on a host of other issues, from abortion to flag burning.

The way that mediating institutions influence preferences is perhaps best illustrated by family life. The family is, of course,

13 Ronald Dworkin, Women and Pornography, NY Rov of Books 36, 41 (Oct 21, 1993). 
the mediating institution that in general determines not only its members' rehgious views, but also their political party affiliation and other views as well. It stands to reason that the family is the most influential mediating institution in most people's lives. For the first two decades of life, and often longer in poorer countries, the family provides both basic nurturing as well as economic stability. Membership in a stable, well-ordered family relationship is critical to success in life. And it stands to reason that the family will be of great importance to preference formation. After all, people are often similarly (if not identically) situated with their families from an economic and social perspective. Thus, people will reasonably conclude that the preferences grounded in the culture and received wisdom of their families are sensible preferences for them to adopt on their own. Indeed, the whole idea of "rebellion" from one's family during the adolescent years is premised on a deep understanding of the fact that people come to be identified so closely with their families that they feel threatened with losing any sense of individual identity. Rebelling is the (generally futile) act of asserting one's personal identity against the group identity represented by membership in the family. According to popular culture, after a brief period of rebellion, one generally returns to the shared values and preferences offered by the family.

Social psychologists find that group membership in general plays a highly significant role in forming people's opinions. ${ }^{14}$ One of the most astounding findings of modern social psychology is that people do not know their own views on a wide range of issues. ${ }^{15}$ Mediating institutions provide a source of pooled values and opinions to which they can defer. For example, labor unions can play a crucial role in the wage example presented above. Unions have the expertise to understand that a 7 percent wage increase in the face of 12 percent inflation and a 5 percent wage cut in the face of zero percent inflation are the same thing. That is why labor unions have so persistently maintained a policy of seeking cost-of-living adjustments for workers. By following the union line, workers can feel more confident that their best inter1964).

14 See Robert E. Lane and David O. Sears, Public Opinion 33-42 (Prentice Hall,

${ }_{15}$ In the field of social psychology, support for the proposition that people do not know their own preferences on a wide range of issues is derived from research showing that preferences often depend on the way that alternatives are presented. See John W. Payne, James R. Bettman, and E.J. Johnson, Behavioral Decision Research: A Constructive Processing Perspective, 43 Annual Rev Psych 87 (1992). 
ests are being advanced-even if the workers themselves have little inclination to carry out real-wage calculations.

Similarly, corporations can define the investment preferences of their constituent members (shareholders, employees, etc.), thereby eliminating their constituents' preference-formation problems over a wide range of decisions. Of course, while management generally makes decisions regarding resource allocation with firms, the fundamental decisions about what line of business to pursue generally have been made long ago. Management is just carrying out the policy. This will be the case unless management can convince the board of directors either that a crisis or a particularly attractive opportunity exists in some new venture or line of business. Indeed, it may be argued that one of the reasons that social psychology finds people to be such bad decision makers is because mediating institutions play such a large role in modern life. In part, people have lost the need-and consequently the ability-to make decisions for themselves.

\section{B. Risk Aversion and Preference Formation}

An important way that mediating institutions can transform preferences is to make people less risk averse. This point can be most rigorously understood with reference to the publicly held corporation.

Basic principles of economic theory posit that economic actors, such as investors and consumers, are risk averse if they are rational. As developed at length above, however, there is no reason to believe that individuals are rational. Rather, in the face of irrationality, the assumption of risk aversion in economic theory can only be supported by positing the presence of an important mediating institution, the market, which causes people to act as though they were rational, even though it would seem clear that individual economic actors do not have sufficient information to behave rationally in the investment context.

If investors are risk averse, they will demand a premium (the so-called risk premium) for accepting risky projects. The risk premium is the excess return beyond what a risk-neutral investor would accept required to entice a risk-averse investor to invest in a particular project. Risk aversion stems from the diminishing marginal utility of wealth; the pain that comes from losing a gamble is greater than the joy that comes from winning that same gamble. For example, a person with a net worth of $\$ 1$ million would decline a million-dollar bet, because the pain of losing everything would be greater than the satisfaction of having one 
more million; she would demand a risk premium before making the gamble.

Markets act as mediating institutions in the sense that markets interpose themselves between individual decision makers and their decisions. Where a decision is made in a market context (as opposed to a political or moral decision such as for whom to vote or what to believe about abortion), individual decision makers accept the price for a product that is generated by the market. Thus, when a person buys a share of stock on the New York Stock Exchange, or when a person buys a banana at the grocery store, the only decision being made is about whether to make the purchase. The decision about what price to pay is set by anonymous market forces. One does not bargain over the price of IBM stock or over the price of bananas. One accepts the price as given.

Thus, the market serves as an important form of mediating institution that saves us from our own irrationahity, at least with respect to the prices we pay for things. Protection for consumers and investors lies in the fact that market forces establish a fair price. As the Supreme Court has observed in the context of the price-setting mechanism for securities: "II]n an open and developed securities market, the price of a company's stock is determined by the available material information regarding the company and its business...."16 And, "competing judgments of buyers and sellers as to the fair price of a security brings [sic] about a situation where the market price reflects as nearly as possible a just price. ${ }^{, 17}$ In other words, in the process of market ordering best described by Hayek, markets can produce rational results out of a large series of uninformed, if not irrational, events. ${ }^{18}$

While markets behave as if all investors were risk averse, the payoffs to particular gambles within a firm are not randomly distributed among all investors. As residual claimants, shareholders stand last in line to receive distributions from insolvent firms, but they are also entitled to receive a disproportionate portion of the profits when things go well. This fact transforms

${ }^{16}$ Basic, Inc. $v$ Levinson, 485 US 224, 241-42 (1988), quoting Peil v Speiser, 806 F2d 1154, 1160-61 (3d Cir 1986).

${ }_{17}$ Basic, 485 US at 246, quoting HR Rep No 1383, 73d Cong, 2d Sess 11 (1934).

18 Friedrich A. Hayek, Economics and Knowledge, in Individualism and Economic Order 33, 54 (Chicago, 1948). 
shareholders' preferences with respect to the risk taking that occurs within corporations.

Suppose that a firm with assets worth 100 goes to its bank for a loan. Suppose also that the firm has 50 in debt outstanding, and 50 in equity. Suppose further that the firm's value of 100 is attributable to the firm's investment in a single project that has a 50 percent chance of paying off 140 and a 50 percent chance of paying off 60 . The firm is worth 100 because $(.5 \times 140)+(.5 \times 60)$ $=(70)+(30)=100$. A bank might be willing to loan the firm 50 for the purpose of retiring other, higher-interest-bearing debt, because even under the worst possible scenario, in which the firm makes only 60 on its investment in this project, the bank would still be repaid in full. But after the loan has been made, the equity holders in the firm have an incentive to shift its funds from the first project into riskier projects. This incentive is known as the problem of moral hazard.

For example, assume that the firm shifts all of its assets into a second project with a 50 percent chance of paying off 180 and a 50 percent chance of paying off 20 . The investment still has a total expected return of 100: $(.5 \times 180)+(.5 \times 20)=(90)+(10)=$ 100. However, there is now a 50 percent chance that the loan will go into default and the bank will not be repaid in full.

But the second investment is superior from the shareholders' perspective. As equity claimants, of course, the shareholders stand in line for payment behind the banks. Thus, in the first investment, the shareholders' investment has an expected value of 50: $(.5 \times 90)+(.5 \times 10)=(45)+(5)=50$. By contrast, the second investment provides the shareholders with an expected return of 65: $(.5 \times 130)+(.5 \times 0)=(65)+(0)=65$. Thus, even though the shareholders have a 50 percent chance of receiving nothing in the second investment, they still prefer it, ex ante, to the first, even though the bank clearly prefers the first investment. A moral hazard exists because the shareholders have incentives to shift their firm's assets from relatively safe investments, such as in the first example, to relatively risky investments, such as in the second.

Just as people can transform the nature of their revealed preferences for risk by buying equity claims in public corporations, so too can individuals transform the nature of their revealed preferences for risk in other areas of life by associating with mediating institutions. For example, people's preferences change when they join a law firm, or even while they attend law school. As I have observed in another context: 
[B]ecause the professional training required to become a lawyer involves a specific, nondiversifiable human capital investment, there are substantial risks associated with legal training. In particular, any exogenous circumstance that reduces society's demand for legal services would greatly reduce the income of lawyers as a group.

... Over the course of a three year legal education, an important transformation takes place. Before entering law school, a student's future income is wholly unrelated to the welfare of the legal profession as a whole. By the end of law school, much of the value of the substantial investment made in obtainning a legal education depends on the future of the profession. ${ }^{19}$

In other words, law school is a mediating institution. During law school, law students become residual claimants on the income of the legal profession as a whole.

Law students are residual claimants on the income of the legal profession in the sense that their welfare is linked to the general welfare of the entire legal profession. Indeed, members of mediating institutions are residual claimants whose welfare is closely linked to the welfare of the institutions with which they are associated. Alumni tend to support their universities because their welfare is (loosely) tied to the way in which their alma maters are perceived. The link may be even more direct. For example, if the societal demand for dentists goes up, the welfare of dentists increases. The power of preference formation that takes place within mediating institutions is so great that these preferences may trump the narrow self-interest of an institution's members. For example, the culture within the dental profession is to promote healthy teeth. This culture has led dentists to promote a number of products, most notably fluoride, that have reduced the demand for their services significantly. However, on other issues, where narrow self-interest does not conflict with dominant culture of the group, dentists act in ways that are consistent with self-interest. Thus dentists are likely to support mandatory insurance coverage for dental work.

The fact that members of mediating institutions are residual claimants clearly enhances the transformative role that such

19 Jonathan R. Macey, Civic Education and Interest Group Formation in the American Law School, 45 Stan L Rev 1937, 1941-42 (1993). 
mstitutions play in the lives of their members. People are more likely to accept the preferences of a particular institution when their personal welfare is hinked to the welfare of the institution. The closer the linkage between the welfare of an individual and the welfare of a mediating institution, the more likely that person is to adopt the preferences of the institution.

Whether preference formation by firms is desirable depends on the abihity of their subgroups to protect themselves from the risk-taking proclivities of rival groups. As shown above, by increasing the riskiness of the firm in which they have invested, shareholders can transfer wealth from other claimants to themselves. In the example, shareholders transferred wealth to themselves from the bank without changing the expected value of the firm itself. But it is easy to show that shareholders can also transfer wealth to themselves from fixed claimants while diminishing the value of the firm. ${ }^{20}$ Similarly, lawyers may "steal" wealth from society by pursuing legal rules that increase the demand for lawyers, while decreasing the net wealth of society. The numbing complexity of the tax code, the rules of civil procedure, the principles of corporate law, all can be explained, at least in part, as efforts to increase aggregate demand for lawyers' services artificially. ${ }^{21}$ Thus, the ability of nonmembers to prevent this net loss is the sine qua non for approval of institutional preference formation; with their reshaped preferences, the members of mediating institutions can no longer be trusted to do it themselves.

And it is by no means clear that other groups are capable of protecting themselves from the ability of mediating institutions to influence the preferences of their members in self-interested ways, and then to galvanize into effective political coalitions in order to transform those preferences into policy. For example, it may not be cost-effective for labor unions to organize opposition to more lawyer-oriented substantive corporate law rules or more complicated tax laws, despite the fact that such laws hurt unions by reducing society's basic capacity for growth. However, the expected costs of evaluating the effects of these sorts of changes and making the effort to oppose them may be greater than the

${ }^{20}$ See Jonathan R. Macey and Geoffrey P. Miller, Bank Failures, Risk Monitoring, and the Market for Bank Control, 88 Colum L Rev 1153, 1162-65 (1988).

${ }^{21}$ See generally Jonathan R. Macey and Geoffrey P. Miller, Toward an Interest-Group Theory of Delaware Corporate Law, 65 Tex L Rev 469 (1987) (making the point that Delaware corporate law is designed to increase the demand for lawyers in Delaware). 
expected benefits. Where this is the case, it will be rational for unions to refrain from opposing such laws.

On occasion, the self-interest of rival groups will offset each other. For example, doctors may organize to combat more liberal rules in malpractice cases, despite the benefits that such rules would provide to lawyers. And business interests such as the Business Roundtable might galvanize into an effective political coalition to oppose needless complexity in the tax laws or corporate law rules that encourage baseless litigation.

\section{Disengagement in Mediating Institutions: The CORPORATION AND BEYOND}

Disengagement, which results when members delegate duties to institutional specialists, is characteristic of mediating institutions. For example, economists view the moderu publicly held corporation as efficient because it separates the firm's risk-bearing and decision-making functions. ${ }^{22}$ The benefits of separation come from shareholders' ability to eliminate nonsystemic risk by diversifying their investments across a portfolio of firms. But shareholders' complete withdrawal from the firm's decision-making process exposes them to costs, as managers may divert shared resources to themselves.

As Michael Jensen and William Meckling explamed in their path-breaking article on the theory of the firm, shareholders, as principals, have delegated to the firm's managers, as agents, the responsibility for running the day-to-day operations of the firms in which they have invested. ${ }^{23}$ Investing shareholders, anticipating divergences between the managers' interests and their own, will seek to limit managers through monitoring and incentive structures for the agents. Similarly, because the managers want to be hired, they will expend resources to guarantee that they will not harm the principals. The costs to the shareholders are known as monitoring costs, while the costs to the managers are known as bonding costs. Even after the managers and shareholders have taken these precautions, their agency relationship will produce residual losses that none of the parties find worthwhile

22 See Eugene F. Fama, Agency Problems and the Theory of the Firm, $88 \mathrm{~J}$ Pol Econ 288 (1980).

${ }_{23}$ Michael C. Jensen and William H. Meckling, Theory of the Firm: Managerial Behavior, Agency Costs and Ownership Structure, 3 J Fin Econ 305 (1976). 
to avoid. These residual losses, however, will not outweigh the benefits of membership, or the firm will cease to exist. ${ }^{24}$

Eugene Fama has argued that the benefits of specialization are the central justification for the organization of the modern, publicly held corporation. ${ }^{25}$ Managers specialize in decision making, while investors specialize in risk bearing. The managers are inefficient risk bearers because their investments are undiversified, while the shareholders are inefficient managers because they have no management skills.

Scholars have pointed out how new, innovative forms of mediating institutions can help existing mediating institutions operate better. For example, Henry Manne has observed how the market for corporate control can make the corporation operate better by helping to align the interests of managers with the interests of shareholders. ${ }^{26}$ Similarly, the emergence and increasing dominance of large institutional investors may mitigate the agency-cost problem by providing more efficient monitoring of the corporation. ${ }^{27}$ The point here is that people's preferences about the investment strategies and the optimal level of risk taking for the firms in which they have invested will be determined by the form that their investments take. In addition, people's ability to disengage themselves from the active management and monitoring of their investments will be determined by the nature of their investments. Certainly it is true that, as a general rule, people with a greater taste for risk might prefer equity investments over debt instruments. But it is also true that future decisions, unforeseen at the time an initial investment was made, will be significantly influenced by the type of investment that one has made. Moreover, this analysis applies with even greater force outside of the investment context. People may have complete discretion about the sort of investments they make. But people often will have less choice about their affiliation with other sorts of mediating institutions, such as their family or their religion. Yet their affiliation with such institutions often will have a dramatic effect on the shape of people's preferences.

24 Id at 323-26.

25 Fama, $88 \mathrm{~J}$ Pol Econ at 290-92 (cited in note 22).

${ }^{26}$ Henry G. Manne, Mergers and the Market for Corporate Control, $73 \mathrm{~J}$ Pol Econ 110, 112-13 (1965) (arguing that mergers are efficient hecause the "high positive correlation between corporate managerial efficiency and the market price of shares of that company" drives managers to maintain a high stock price to prevent takeovers).

${ }^{27}$ See Mark J. Roe, Some Differences in Corporate Structure in Germany, Japan, and the United States, 102 Yale L J 1927, 1929-30 (1993). 
This analysis of disengagement and preference formation shows the importance of understanding people's responses to the peculiar incentives of the corporate form. For example, it would affect the debate over the optimal capital structure of firms-the most important current debate in corporate finance-in the following manner.

As Stewart Myers recently observed, "[t]he optimal balance between debt and equity financing has been a central issue in corporate finance ever since Modighiani and Miller [ ] showed in 1958 that capital structure was irrelevant." ${ }^{28}$ We know that "[i]f there is an optimal capital structure [for firms], it should reflect taxes or some specifically identifled market imperfections."29 Preference formation and disengagement, if firms anticipate them, can play an important role in determining capital structure.

My analysis indicates that the existing "life cycle" approach to securities issuance by firms should be rejected..$^{30}$ The life cycle approach predicts that, since bank financing is unambiguously more costly than financing through the public offering of securities, firms obtain bank financing when they are too small to afford a public offering of securities. Contrary to expectations, we see large, established firms using substantial amounts of bank financing, often at the same time as financing from the public debt and equity markets. This can be explained by the principles of disengagement and preference formation.

Assume that some firms will find it easier than others to shift the allocation of their assets from relatively safe investments to relatively risky investments. Firms that can easily shift to risky investments present lenders with a greater moral hazard problem. Since firms with firmer investment commitments cannot transfer wealth to themselves in this way, they allow lenders to disengage themselves, devoting their energies to other projects. Lenders will anticipate that disengagement will not be possible when they extend credit to more shifty firms.

Shifty firms will find it costly to enter the securities markets for debt, because the public debt markets are characterized by systematic disengagement. But since banks are not disen-

${ }^{28}$ Stewart C. Myers, Still Searching for Optimal Capital Structure, 6 Continental Bank J Applied Corp Fin 4 (1993).

29 Id.

${ }^{30}$ See generally Richard A. Brealey and Stewart C. Myers, Principles of Corporate Finance 339-65 (McGraw-Hill, 4th ed 1991). 
gaged-they quite actively monitor the activities and performance of their debtor firms-even the largest shifty firms will prefer bank financing.

It is possible to generalize from the corporate context to other forms of mediating institutions. The types of mediating institutions that one is affiliated with will determine the extent to which one can enjoy the luxury of disengaging from active involvement in the activities of the institution. And just as the securities markets and the investment contract that one has with a firm will determine the risk preferences of investors, so too will other forms of mediating institutions influence people's preferences in fundamental ways.

Unfortunately, the current scholarship on the economic nature of the firm, with its emphasis on the efficiency gains from organizing institutions to minimize information costs and better allocate risk, has not been extended to inform studies of government or other forms of mediating institutions. Since competitive capital markets force corporations to evolve more quickly than other forms of mediating institutions, methods borrowed from the corporate context are likely to be the most advanced.

Like the publicly held corporation, other forms of mediating institutions are designed to permit or even to encourage disengagement. Political parties are one example. Clearly, political parties serve a variety of functions as mediating institutions. To begin with, political party affiliations supply voters with information, serving the same function for politicians as brand names play for products: they are "cheap sources of information about which candidates are likely to best serve the interests of voters or contributors. ${ }^{31}$ While this explanation for political parties has a surface plausibility, it seems incomplete, because the quality of the signal sent by party affiliation is weak at best. ${ }^{32}$ This is because political parties in the United States lack ideological cohesion. ${ }^{33}$ In fact, on most issues, American political parties do not offer clearly different choices. Both parties support popular programs and eschew unpopular ones. ${ }^{34}$

Political parties play much the same role for politicians that public corporations play for investors. Just as corporations permit

${ }^{31}$ Sam Peltzman, Constituent Interest and Congressional Voting, $27 \mathrm{~J}$ L \& Econ 181, 197 (1984).

${ }_{32}$ See Macey, 89 Mich L Rev at 16-17 (cited in note 12).

33 Id at 10-11.

34 See Gerald M. Pomper and Susan S. Lederman, Elections in America: Control and Influence in Democratic Politics 167-73 (Longman, 2d ed 1980). 
specialization and disengagement by investors, so too do political parties permit specialization and disengagement by politicians.

Much of the existing work on political parties presumes that voters have fixed preferences over the issues relevant to the political party, and that they select their party affiliation based on how closely the rival parties' positions are to their own points of view. Steven Calabresi's contribution to this Special Issue provides an example of how scholars generally view political parties. Professor Calabresi takes the view that political parties reduce "political agency costs" by "tying tens of thousands of office-holding political actors to a fairly defined set of programs and ideas for which they will ultimately be held accountable. ${ }^{p 35}$ In other words, Professor Calabresi takes the view that people join political parties with fixed preferences about issues, and use political parties as a means of transforming those preferences into policy by limiting the ability of political actors to diverge from their promises to respect voters' preferences once elected. This account seems unconvincing for at least three reasons.

First, at least with respect to the American experience, political parties offer no mechanism through which political parties can control members who stray from the party line. This is because American political parties cannot sanction members who do not exhibit party loyalty. In the absence of an ability to control members, political parties cannot make a credible commitment to control political agency costs.

Second, not only do political parties not sanction their members, but political parties in America differ from one another only marginally with respect to their programs and ideas. In other words, Professor Calabresi's assertion that political parties offer voters a "fairly defined set of programs and ideas" seems highly overstated. ${ }^{36}$

Finally, the assumption that voters have fixed preferences about issues seems subject to serious challenge. As developed above, it seems clear that voters do not have rational preferences. Because of this, voters are attracted to mediating institutions, in part, because such institutions can overcome some of the problems posed by irrationality by structuring people's belief systems for them.

35 Calabresi, $61 \mathrm{U}$ Chi L Rev at 1526 (cited in note 4).

${ }^{36}$ See Macey, 89 Mich L Rev at 16-17 (cited in note 12) (making the point that the ideological signal sent by party affiliation is quite weak). 
Thus, party affiliation may determine voters' preferences over many issues, rather than the other way around. In other words, voters do not tell political parties what positions to take, political parties tell voters what positions to take, on at least some issues. Clearly, for some issues, like abortion or crime, people are likely to hold preferences that are not influenced by political party affiliation (although these preferences probably will be influenced by other mediating institutions, such as religious organizations, neighborhood organizations, or family affiliation). However, on other issues, like trade and foreign policy, pohtical parties will lead rather than follow with respect to preference formation. The task of responding to voter preferences then falls to individual politicians.

Politicians have limited time, power, and influence. Not even the President can credibly guarantee to a particular constituency that she will be able to pass a particular piece of legislation. But by relying on mediating institutions, politicians can improve their performance. Just as shareholders in firms specialize and diversify, so too do politicians with party affiliations specialize and diversify by becoming champions of particular interest groups and particular causes. Just as individual investors can purchase managerial expertise by buying stock in a particular company, or individual workers can obtain negotiating expertise by joining a union, so too can interest groups buy political expertise by affiliating with a particular political party.

Political parties represent broadly divergent interests: doctors, lawyers, bankers, truckers, suppliers of military hardware, and even government bureaucrats. These groups are clients of political parties; they will care deeply about some issues and be relatively indifferent about other issues. ${ }^{37}$ Political parties provide the forum through which these interest groups can trade support with each other. By supporting a particular political party that favors the interest of both truckers and doctors, truckers and doctors can support the political goals of the other group in exchange for support by that group for its own goals. It is simply too expensive for individual politicians, or individual interest groups, to reconcile all of the competing interests necessary to ensure that their views will be reflected in policy outcomes. Thus, for example, a politician with close ties to labor unions can make a more credible commitment to support the

${ }^{37}$ See Cotton M. Lindsay and Michael T. Maloney, Party Politics and the Price of Payola, 26 Econ Inquiry 203, 205 (1988). 
programs favored by those unions if she is affiliated with a political party with whom she can bargain on behalf of her union clients. By affiliating with a political party, the politician can exchange her votes on issues of little relevance to the union for the support of other politicians on labor issues.

This is the role that political parties serve. Politicians cannot win on every issue, but by affiliating with a political party politicians obtain the advantages of diversification; they will be the winners on some issues. Affiliating with a political party enables politicians to trade political support over issues they care deeply about for promises of future support to other members of the same party on issues those politicians care about. In this way, party affiliation enhances the value of the votes of individual pohticians.

Similarly, political party affiliation allows individual politicians to specialize in particular subject areas, safe in the knowledge that following the "party line" in other areas will be the most effective strategy. The disengagement point is the same. Politicians do not have to become knowledgeable about all relevant issues. The party's position constitutes a source of information. Thus, just as investors who do not own diversified portfolios of stock do not fare well against investors who do, politicians who are not members of political parties do not fare well against politicians who are. While this point is somewhat counterintuitive, because most people are taught that political parties are organized to serve the interests of voters, I would posit that, upon reflection, many would agree that political parties are designed to serve politicians' interests at least as much as they are designed to serve voters' interests. After all, politicians have far more at stake in choosing a party affiliation than do individual voters.

Indeed, the benefits of political parties as mediating institutions provide the best available explanation of this phenomenon, since political parties do not convey much of a signal to people about the ideological orientation of their members. Nor do political parties provide much information about the positions favored by particular politicians on particular issues. As Sam Peltzman has shown, party membership is not necessarily a fundamental source of voting patterns for politicians. ${ }^{38}$ Instead, political parties provide a forum through which politicians can use their political power more efficiently, and at lower risk.

${ }^{38}$ Peltzman, $27 \mathrm{~J} \mathrm{~L} \&$ Econ at 197 (cited in note 31). 
Following Ronald Coase's lead, the political party can be envisioned as a mechanism by which transactions that would otherwise take place in markets come to take place within firms. ${ }^{39}$ Market transactions take place in order to benefit from the information generated by the price-setting mechanism of the marketplace. ${ }^{40}$ Transactions take place within firms in order to capture the savings in transactions costs that firms enjoy over markets. ${ }^{41}$ In particular, where there are contracting costs, such as the costs associated with opportunistic behavior, market participants will have strong incentives to reorganize their activities within firms. For example, where a contract calls for one party to make a firm-specific capital investment in a fixed asset in exchange for a fixed payment of cash, the contract leaves the party making the investment open to exploitation by the other party. The other party will have an incentive to renegotiate the contract once the first party has made the firm-specific investment, which, by definition, cannot be redeployed to an alternative use. By integrating vertically, firms can eliminate the incentives to act opportunistically by exploiting firm-specific capital investments because all of the gains from specialization will be captured within a single firm.

Similarly, politicians make exploitable investments in developing relationships with particular interest groups, and in developing knowledge and expertise in particular subject areas. Joining political parties, like joining in firms, helps politicians to reduce the risks associated with making these sorts of investments. The politicians who constitute a political party represent a whole set of nondiversifiable investments in a wide range of policy issues and positions. Party membership allows party members to diversify their investments in policy issues, to disengage from a wide range of issues, and hence to specialize in a small number of policy areas. At the same time, when an individual politician runs for reelection, his party membership enables him to claim credit for the accomplishments of his party, even those for which he was only tangentially responsible.

Politicians seeking to effect changes in legal rules could attempt to bargain with other politicians individually in a market setting. Alternatively, politicians could join a "firm"-that is, a political party-in order to economize on transaction costs by re-

\footnotetext{
${ }^{39}$ See R.H. Coase, The Nature of the Firm, 4 Economica 386 (1937).

40 Id at 394-95.

41 Id at 391.
} 
placing the price mechanism that characterizes market transactions with the long-term contracting that characterizes firms and political parties.

The disengagement hypothesis also allows us to see the U.S. Constitution as a special form of mediating institution, which permits disengagement by the general populace from the lawmaking process during times of ordinary politics. The American constitutional system is designed to raise the decision costs of government. ${ }^{42}$ Many features of U.S. constitutional design, including the bicameral legislature, the rules regarding the size and composition of the House and the Senate, the executive veto, the presentment requirement, the separation of powers, and judicial review, are structural devices designed to make it more difficult to pass laws. ${ }^{43}$ The principal effect of these features is to permit disengagement by ordinary citizens by reducing the efficacy of rent-seeking by organized interest groups, thus reheving ordinary citizens of some of the burden of organizing into political coalitions to reduce the rent-seeking of others. Hamstringing the government permits ordinary citizens to pursue their own interests, should they so desire. Because the Constitution inakes it difficult for Congress to pass laws, individual citizens are not forced into a preoccupation with political life, but instead can lead private lives free from fear of government intervention and the need to lobby for forbearance from excessive regnlation. The system of checks and balances, of which the separation of powers is a part, permits disengagement by citizens who recognize that otherwise, during times of ordinary politics, well-organized groups will cause elected representatives to enact laws that reduce net social welfare in order to benefit the well-organized groups. As Bruce Ackerman has observed, the principal defense given in The Federalist Papers for ratification of the new Constitution was that it laid the "foundations for a different kind of politics-where well-organized groups try to manipulate government in pursuit of their narrow interests. ${ }^{34}$

There are only two ways that ordinary citizens can deal with the coalitions formed by these interest groups. The first is by forming interest groups (which, of course, are mediating institu-

42 See Jonathan R. Macey, Thayer, Nagel and the Founders' Design: A Comment, 88 Nw U L Rev 226, 239 (1993).

${ }^{43}$ See Jonathan R. Macey, Promoting Public-Regarding Legislation Through Statutory Interpretation: An Interest Group Model, 86 Colum L Rev 223, 247-50 (1986).

4 Bruce A. Ackerman, The Storrs Lectures: Discovering the Constitution, 93 Yale L J 1013,1020 (1984). 
tions themselves) in order to make sure that their preferences are well represented in the political decision-making process. The second is by establishing a constitutional structure that makes it more costly for laws to be passed in the first place. The Framers of the U.S. Constitution recognized that "the future of American politics will not be one long, glorious reenactment of the American Revolution." ${ }^{45}$ Rather, with the exception of a few, largely unrepresentative activists and academics, people for the most part want to disengage from the political process. That is, they want to ignore politics and pursue happiness and self-fulfillment in a private rather than a public setting. Such pursuits are impossible in the presence of a monolithic central government run by selfish politicians who, by and large, seek to transfer wealth from the politically uninterested to the politically well-connected. The constitutional structure, acting as a mediating institution, serves two goals simultaneously: monolithic central government is prevented, and disengagement is fostered.

Thus, we see that, in a wide variety of settings, mediating institutions permit disengagement so that people are free to channel their interests and energies however they see fit. A properly functioning constitutional scheme serves as a mediating institution that permits disengagement by raising the decision costs of government. Absent such constitutional provisions, citizens would be forced into the pubhic sphere in order to resist the activities of interest groups. According to the interest-group or economic theory of legislation, market forces prompt politicians to enact laws that serve private rather than public interests. Statutes are commodities that are supplied by lawmakers to the political groups or coalitions that outbid competing interest groups. The process by which interest groups seek to obtain favors from government is called "rent-seeking." Individuals capture rents when they obtain payments in excess of the market price for the use of economic assets (such payments are known as economic rents). Rent-seeking imposes considerable costs on society:

The most widely understood external costs are those that third parties encounter when they attempt to block legislation that threatens to transfer wealth from those third parties to the rent-seeking interest groups. In addition, rentseeking is inefficient because it can result in several forms of

45 Id. 
deadweight social losses. For example, ... interest groups seeking wealth transfers must expend resources to obtain those transfers .... Deadweight social losses also occur when legislation creates truly unnecessary regulation that imposes greater costs on some firms than others, thus giving certain firms a competitive edge. Where such regulations exist, deadweight loss results as the parties subject to the regulation must expend resources to comply with the regulation.

Another, more subtle cost of interest group regulation ... is that it prompts economic resources to be diverted from more valued to less valued-but unregulated-uses. Finally, the power of the government to effect wealth transfers imposes costs even on markets that appear to be operating free of governmental intrusion; even in such unregulated markets economic actors must expend resources to keep their markets clear of governmental regulation. ${ }^{46}$

The point here is that raising the decision costs of government permits disengagement by enabling citizens to avoid the costs imposed by rent-seeking without incurring the substantial costs of organizing into effective political coalitions in order to deter unwanted governmental activity. However, just as it is inefficient for shareholders and managers to eliminate completely all agency costs within corporations, it is also inefficient for constitutions to eliminate completely all agency costs within government. This is because rent-seeking cannot be eliminated without cost. There are direct costs associated with maintaining constitutional safeguards such as the separation of powers, the executive veto, and the independent judiciary. In addition, there are indirect costs: these sorts of devices make it more difficult to pass all laws, both good and bad.

As a result, there will be an optimal, nonzero level of constitutional safeguards against rent-seeking, and an optimal level of disengagement from the political realm by citizens. Like shareholders, a rational citizen will only expend resources to become engaged in the political sphere until the costs of such expenditures equals the expected benefits in the form of what is, at least from the perspective of that citizen, better government. 
This mediating-institutions model faces a competing conception of citizens' relationship to the structure of their government. The alternative model, often referred to as classical republicanism, has its origins in the notion, traceable to Aristotle and embraced by scholars to this day, that civic involvement is not just a good thing, but is the best life for human beings. ${ }^{47}$ This approach values citizen participation in government as an end in itself. The premise underlying this approach is that any system of government lacking sustained, widespread citizen participation and involvement will suffer because its members will not develop the feelings of "empathy [and] social solidarity" necessary to sustain a liberal democracy. ${ }^{48}$ Some classic or civic republicans take the view that a system lacking widespread and frequent citizen participation is necessarily oppressive, ${ }^{49}$ while others restrict themselves to the view that civic involvement and political engagement is "often an important individual and collective good. $" 30$

This vision of public life has direct implications for the theory of mediating institutions being developed here. This is because mediating institutions are an important forum through which citizens can express themselves in public life. As Cass Sunstein has observed:

Citizenship, understood in republican fashion, does not occur solely through official organs. Many organizations-including labor unions, religious associations, women's groups of various sorts, civil rights organizations, volunteer and charitable groups, and others, sometimes marking themselves outside of and in opposition to conventional society-serve as outlets for some of the principal functions of republican systems. These functions include the achievement of critical scrutiny of existing practices, the provision of an opportunity for deliberation within collectivities, the chance to exercise citizenship and to obtain a sense of community, and the exercise of civic virtue, under-

47 See Cass R. Sunstein, Beyond the Republican Revival, 97 Yale L J 1539, 1547 n 37 (1988); Hannah Arendt, On Revolution 217-85 (Viking, 2d ed 1965).

${ }^{48}$ Sunstein, 97 Yale L J at 1547.

49 See id. See also Gerald E. Frug, The City as a Legal Concept, 93 Harv L Rev 1059, 1067-70 (1980).

so Sunstein, 97 Yale L J at 1547. 
stood as the pursuit of goals other than self-interest, narrowly conceived. ${ }^{1}$

In other words, the republican vision of the role of mediating institutions, at least as developed by Cass Sunstein, views such institutions as providing a mechanism for facilitating engagement. In sharp contrast, the model of mediating institutions I am presenting here regards such institutions as providing a mechainsm for avoiding such engagement.

Moreover, the vision of mediating institutions presented by Professor Sunstein describes such institutions as providing a device by which people can transcend their own self-interest. Again, this contrasts with the model of mediating institutions presented here. First, as shown above, mediating institutions are devices by which people can express their own self-interest more effectively. They are not institutions that cause people somehow to subjugate their own self-interest to the greater good.

Because people often simply accept the preferences offered by their mediating institutions, it would not be accurate to say that people's preferences are subjugated to them. In those cases where people have formed preferences independently (whether on the basis of a signal from another mediating institution or on some other basis) and those preferences conflict with the preferences of a mediating institution, then people will either: (1) change their preferences to conform to the preferences of the institution; (2) ignore the preferences of the institution (as is the case with prochoice Catholics, or antiabortion Democrats); or (3) abandon their affiliation with the mediating institution entirely.

Given the existence of these options, and the general lack of coercive power of nongovernmental mediating institutions, it hardly seems plausible that mediating institutions subjugate people's preferences. Sometimes people's preferences are transformed by mediating institutions, and sometimes people have no preferences with regard to a particular issue, in which case their preferences are likely to be formed by their mediating institutions. But in neither case can their preferences be said to have been subjugated to those of their mediating institutions. I do wish to acknowledge, however, the important point that sometimes mediating institutions take positions that are clearly inconsistent with the interests of at least some of their members. But even where this happens, it cannot be said that members' inter-

s1 Id at 1573. 
ests are being subjugated to the interests of the institution as long as membership represents a positive-sum game. Membership in a mediating institution, like other forms of contractual and quasi-contractual relationships, involves quid pro quos. Sacrifice does not equal subjugation. As long as the sacrifice is compensated for by the presence of benefits in other aspects of the relationship, it is false to say that membership in a mediating institution involves the subjugation of individual preferences to those of a group.

Second, as emphasized earlier, mediating institutions are devices through which people's preferences actually are shaped and molded. They are not institutions through which people's preferences are somehow subjugated to the greater good. This point is shown by a simple experiment. Consider a mediating institution on the hines of those described by Professor Sunstein. Members of that institution have certain preferences regarding the issues of concern to the institution. The experiment compares the intensity of the members' preferences with the intensity of the preferences of nonmembers with respect to those same issues. Suppose one were to compare the preferences of: (1) labor union members with nonmembers, regarding labor issues (such as the legality of hiring permanent replacements for striking workers); or (2) members of religious groups with people unaffiliated with rehgious groups, regarding religious issues (such as the legality of school prayer); or (3) members of women's groups with nonmembers regarding issues of particular salience to women (such as comparable pay, federal funding of abortion, or standards of proof in rape cases).

I think there is little doubt that the preferences of the members of all of three mediating institutions refiect the self-interest of their members. The assertion that mediating institutions subordinate this self-interest to broader community interests simply cannot withstand scrutiny. The reality is that mediating institutions provide a forum through which the self-interest of members can be amplified and directed. Indeed, a primary reason why these mediating institutions were formed in the first place was to provide a vehicle through which the self-interest of similarly situated individuals can find political expression in an effective, cost-effective manner. Put another way, virtually every person in society belongs to a complex web of mediating institutions in the form of groups and coalitions. But "it is to this web of groups and 
coahtions rather than. to the nation as a whole that an individual's primary allegiance belongs . . . ."52

Thus, in a pluralist society:

it is simply not realistic to think that an individual will put the interests of the community ahead of his own because, in all likelihood, the individual has pre-existing commitments to a host of other entities, such as religious groups, ethnic groups, and labor and professional organizations. The allegiance to any one of these groups is likely to trump any commitment to as amorphous a concept as "the community." The question, then, is not ... whether one values community; the questions are which community [mediating institution] among the several to which one belongs does one value most at any given time, and how does one resolve differences when there is conflict among the various communities with which one identifies. ${ }^{53}$

The republican conception of government as a mediating nistitution through which self-interest could be subordinated to civic virtue was specifically considered and rejected by the Framers of the American Constitution. ${ }^{54}$ In its place, the Framers embraced a conception of mediating institutions consistent with the conception advanced in this Article. The Framers recognized that, while mediating institutions were powerful devices for advancing the interests of their members, such institutions are so powerful that they hold the potential to cause the "instability, injustice and confusion," as well as the "spectacles of turbulence and contention," that had beleaguered and perhaps doomed earlier democracies. ${ }^{55}$

Thus, consistent with the point made here that mediating institutions are desirable because they permit disengagement, constitutional safeguards that raise the decision costs of government are desirable precisely because they facilitate disengagement by limiting the efficacy of other mediating institutions, namely special interest groups. In other words, the only cure for the external harms caused by mediating institutions are other, more universal mediating institutions that can channel and con-

52 Jonathan R. Macey, The Missing Element in the Republican Revival, 97 Yale L J 1673,1679 (1988).

s3 Id.

54 Id at 1674-79.

${ }_{55}$ Federalist 10 (Madison), in Clinton Rossiter, ed, The Federalist Papers 77, 81 (Mentor, 1961). 
trol the self-interest expressed in the more narrowly focused mediating institutions.

\section{COERCIVE EFFECTS}

As the previous discussion shows, many of the benefits of membership in mediating institutions come in the form of costs imposed on other groups. Thus, the primary problem with mediating institutions is not that they coerce their members-who chose their membership-but rather that they force nonmembers to spend resources fighting off the costs that mediating institutions seek to extract from them.

\section{A. Third-Party Costs}

Mediating institutions solve collective action problems for their members. Homeowners associations can make even dangerous, inner-city neighborhoods safer by organizing neighborhood block-watch programs or by organizing escort services for members travelling during the evening. Professional associations of lawyers, doctors, or research scientists offer organized forums for the collection and presentation of research ideas, and awards and recognition to inspire productive members. Political parties allow members to increase their power by enabling them to exchange information and political support in some areas for promises of political support from other party members in areas of special concern. Party affiliation also economizes on information costs and permits members to diversify their investment in policy issues. Similarly, corporations permit investors to obtain the advantages of specialization and diversification by separating the critical functions of management and risk taking. So long as membership in an institution is voluntary, it is impossible to imagine that it does not offer significant personal or professional advantages.

These benefits, however, often come at the expense of other people. As McCormick and Tollison have explained, once a mediating institution has been formed-even for the most benign, public-regarding reasons-its leaders will be inclined to turn the activities of the group toward obtaining wealth transfers from others:

[Mediatnig institutions] that have already borne ... start up costs, for reasons unrelated to lobbying, will have a comparative advantage ni seeking transfers and will therefore be more successful in procuring transfers as a result. This is 
simply a point about jointness in production. Some groups will be able to produce political lobbying as a by-product of performing some other function, thereby avoiding start-up costs for lobbying. There are many examples of such groups in the economy, among which are labor unions, trade associations, corporations, and the like. ${ }^{56}$

In other words, even where a mediating institution is formed for benign purposes, there is a pervasive danger that its focus will be diverted from self-improvement to rent-seeking. Mediatnig institutions will also hurt other groups directly. Take the crime-fighting homeowners associations described above. The most probable result of their efforts will not be to reduce the overall crime rate, but ouly to shift criminal activity to other, less organized neighborhoods. If so, the benefits of these associations at best reflect an externality imposed on outsiders. There may even be net social costs-as, for instance, if they shift crime to neighborhoods that are more expensive to police.

\section{B. Third-Party Coercion}

Mediating institutions not only impose costs on nonmembers, they can coerce the formation of rival groups. A homeowners association like the ones described above may force surrounding neighborhoods to form anticrime groups of their own; a cartel may force its victims to band together to defend their economic interests; a group of planitiff's attorneys that successfully lobbies for liberalization of the rules for suing tortfeasors will create a demand for an association of defense lawyers. At most, this is coercion; it forces the creation of new groups and deprives rivals of the opportunity for disengagement. At a minimum, mediating institutions create a demand for other mediating institutions.

\section{Coercion of Members}

Of course, mediating institutions exert coercive power in less subtle ways; their coercive power over their own members is generally recognized. Members must make sacrifices, including sacrifices of personal freedom, to meet the conditions of membership. This is not to say that these sacrifices are greater than

so Robert E. McCormick and Robert D. Tollison, Politicians, Legislation, and the Economy: An Inquiry into the Interest-Group Theory of Government 17 (Martinus Nijhoff, 1981). 
the costs to the institution of adding a member. And, where joining is voluntary, mediating institutions cannot exist unless the benefits of membership outweigh the costs.

The point I wish to make here is that the institutions demanding the greatest sacrifices of their members are best equipped to provide the greatest benefits. This is because mediating institutions provide collective goods-that is, goods that benefit all members, whether or not they contribute. Lawyers benefit from barriers to entry in their profession regardless of whether they pay dues to the American Bar Association; residents of neighborhoods protected by homeowners associations benefit from reduced crime, whether or not they join the neighborhood watch. As a result, as Mancur Olson has observed:

Since any gain goes to everyone in the group, those who contribute nothing to the effort will get just as much as those who made a contribution. It pays to "let George do it," but George has little or no incentive to do anything in the group interest either, so . . . there will be little, if any, group action. The paradox, then is that . . . large groups, at least if they are composed of rational individuals, will not act in their group interest. ${ }^{57}$

As a result of these so-called free-rider problems, only those mediating institutions that are able to employ coercion of some kind will ultimately succeed. For example, labor unions have proved successful, in large part, by making dues paying compulsory and automatic, ${ }^{58}$ and lawyers have proved successful, in large part, by making bar membership a condition to entry in the profession, just as doctors have done in their profession.

Formal coercion of members is not the only way to succeed. Group members often depend on membership for self-esteem, self-image and self-identity. The threat of exclusion that comes from nonconformity can be a powerful coercive tool in itself. Obviously, exclusion from a mediating institution like the family can be a powerful coercive device. But exclusion from other, less encompassing mediating institutions can have dramatic effects as well. Exclusion from union membership can mean unemployment in a chosen profession. The same is true for exclusion from bar membership for lawyers. Exclusion from a church, synagogue, or

${ }^{57}$ Mancur Olson, The Rise and Decline of Nations: Economic Growth, Stagflation, and Social Rigidities 18 (Yale, 1962).

${ }^{68}$ Id at 21. 
other rehgious organization can mean complete ostracism from one's social community. Indeed, virtually all mediating institutions, even informal social cliques, use the threat of exclusion as a mechanism for controlling the behavior of their members.

\section{CONCLUSION}

I have tried to show that mediating institutions focus, anphfy, and shape the interests and policy preferences of their members. Members rely on their institutions for information about what they should beheve. As the example of the public corporation makes clear, they will also find that even their independently informed preferences are sharpened, and often shaped, by their membership.

Mediating institutions permit institutional specialization that compensates for people's inability to accurately assess risk and uncertanity. Disengagement from these assessments is perceived by members as a distinct and liberating benefit.

The phenomena of preference shaping and disengagement have important social imphications. If people choose to rely on institutional agents, then the common presumption that they will be better off if they are given more rights is erroneous. Because people's preferences over a wide range of issues are either indeterminate, or actually determined by the mediating institutions to which they belong, they would not know (or care) what to do with more rights if they had them.

Because it takes resources and effort to formulate the opinions necessary to exercise rights, people who prefer disengagement may prefer not to be given additional rights. The cost of exercising such rights could require them to defect from their mediating institutions, which may well provide benefits far greater than those accruing from the new rights. Thus, for example, I think it hikely that those members of labor unions who seldom vote, but welcome the political leverage of their unions, would give up their right to vote in exchange for their unions' aggrandizement. At any rate, the basic presumption that people prefer to participate in democratic decision-making institutions must be tempered by the realization that people might rather delegate their votes and devote themselves to other things.

As the world becomes more complex, the disengagement permitted by mediatimg institutions appears to be not only desirable, but inevitable. It simply is not possible for people to form opinions on the dizzying array of social, pohtical, and economic alternatives presented by modernity. Membership in mediating 
institutions enables people to discover what their preferences are by linking themselves to organizations through a complex process of escalating commitments to such organizations. Mediating institutions help protect people from some of the consequences of their own irrationality, inconsistency, and uncertainty in much the same way that the price-setting mechanism of product and securities markets protects consumers by setting prices.

The account of mediating institutions presented here contrasts sharply with the aspirational, participatory view of pohtical and social life offered by civic republicans. This aspirational view considers engagement in civic, cultural, and political affairs to be a virtue that society should encourage, if not compel. In other words, the basic presumption that people prefer to be part of the decisional processes that affect their lives and to participate in democratic institutions must be tempered by the realization that people may prefer to have otlier people make decisions for them so that they will be free to do other things.

The commonly held view that all citizens should vote, and that countries with higl voter-participation rates are more successfully democratic than countries with low voter-participation rates, is but one manifestation of this perspective. By contrast, the account of mediating institutions presented here yields a much different conclusion about this aspirational view of modern life. Citizens will deal with complexity by specializing in certain splieres of life. These spheres are likely to focus on such manageable areas as one's religion, family, and career. Only in times of crisis or dissatisfaction should we expect to observe wholesale departures from people's areas of specialized interest and concern. After all, the process of developing opinions and forming preferences consumes precious resources, not the least of which is time. People would prefer to marshal these resources, conserving them for those areas of life they find most important. Thus, low voter turnout rates and a general lack of participation in political life can be viewed as signs of the success of mediating institutions at enabling people to channel their energies in the areas they most prefer.

But this is not to say that mediating institutions are without coercive effects or influence. However, contrary to popular belief, the problem of coercion is not that mediating institutions force their members to do things that are not in their interest. Coercion of members is not a general problem because most mediating institutions compete for members. Even rehions worry about "consumer satisfaction" these days. And at a certain age, one can 
withdraw from family hife if one so chooses. Thus, so long as membership in a mediating institution is not coerced, coercion in general is not a problem. Rather, the coercive effects of mediating institutions arise because of the third-party effects that mediating institutions have. To the extent that mediating institutions are successful in transforming their own goals into policy, such institutions will have a coercive effect in the sense that they will force other mediating institutions whose interests are threatened to galvanize into effective pohtical coahtions in order to neutralize the effects of the first institution. Similarly, successful mediating institutions will have an effect on other institutions by increasing the demand for membership in such institutions among people who feel threatened by their activities. Thus, for example, where a lawyers' organization is successful in making lawsuits easier, doctors' organizations will be "coerced" into action to counter this threat. And doctors will be prompted to support their organizations more fully in order to counteract the activities of the lawyers. And so it goes.

The point here is not to reach any final conclusion about whether the global effects of mediating institutions are positive or negative. Such institutions provide private benefits to members, but may also impose social costs on society as a whole. Whether the benefits exceed the costs is an empirical question. The answer to this question is likely to vary from organization to organization and from issue to issue, depending, among other things, on how much the activities of one institution prompts a reaction by other institutions.

Rather, the goal of this Article has been to examine the role that mediating institutions actually play in a complex world in which the high cost of information has produced an acute need for specialized decision makers. The Article has shown that mediating institutions fulfill this need for specialized decision makers. In doing so, such institutions permit members to disengage themselves from decision making in certain areas, thereby allowing them to specialize in those areas of life that hold the greatest interest and the greatest promise for personal fulfillment. In addition, mediating institutions deeply influence and sometimes actually shape the preferences of their members in important ways by signalling their members what they should believe. In doing so, mediating institutions resolve the difficulty presented by modern psychologists such as Kahneman and Tversky who have shown that people are often not rational decision makers. As long as people can delegate decision making to specialized 
decision makers in the form of mediating institutions, their lack of well-ordered preferences is of no concern. 